\title{
The Cultural Biography of a Western Australian War Memorial.
}

\section{John R Stephens}

In common with other western countries, there is resurgence in war commemoration in Australia indicating a serious pursuit of identity and a national story on a collective and personal level. A widespread academic and popular interest in war memory and material culture such as war memorials has emerged. War memorials often find their way on to heritage registers. This paper advances cultural biography as an approach to determine the significance of war memorials arguing that this may give a deeper understanding of its community meaning than present methods. Emerging in archaeology cultural biography considers the way that social interactions between people and objects over time create meaning. Using the Katanning war memorial statue in Western Australia as a case study, this paper argues that a cultural biographical approach may uncover a deeper cultural significance resulting from a focus on relationships than from the traditional focus on the memorial as object.

Keywords Cultural biography, war memorials, commemoration, memory, cultural significance.

\section{Introduction}

War memorials are complex places at the confluence of issues of memory, honour, sacrifice, grief, loss and citizenship. For those that build them, they are significant sites that can heal and transmit messages of sacrifice and the cost of war across generations. While their meaning may change over time, they remain informed by the politics of remembering and forgetting. Through constant ritual use they are transformed from passive representational spaces into dynamic landscapes of ideology (Osborne 1998, p. 436). This paper is about war memory, commemoration, war memorials and specifically 
how the techniques of 'cultural biography' may be employed to help uncover the meaning of war memorials to their communities.

As with many other parts of the world, war commemoration and war remembrance in Australia is on the rise witnessed by greed for war memory in popular culture through books, films, re-enactments and battlefield tourism. The 'commemorative frenzy', as Scates (2009) describes this rise, is part of a worldwide 'memory boom' and by a pervasive fascination with the past originating in the 1980s and continuing unabated to our own time. This is attributed to 'a deep nostalgia for the past and a search for traditions within a society without rituals' (Scates 2009, p. 63). Memory becomes a 'crucial site of identity formation' (Todman 2009, p.63) that places war memorials as sites of cultural identity, heritage and significance.

The current literature on war commemoration is large, and it indicates a widespread academic and popular interest in war memory and its tangible and intangible effects. Global scholarship on war memorials and commemoration has spawned innumerable texts that include the seminal work of Alan Borg (1991), Jay Winter (1995) and Alex King (1998). Recently, Savage (2009) and Erika Doss (2010) place current commemorative passion and memorial design in the United States into perspective. In Australia, Ken Inglis's Sacred Places (1998) was followed by other studies on Australian war commemoration by Scates (2006, 2009) and Ziino (2007) among others - although interest in war memorials, specifically, remains limited. Focus on World War One increases as the anniversary of that war approaches in 2014. As they age, war memorials are increasingly being considered as 'cultural heritage' a category that aligns with their primary purpose of mnemonic markers and focus of war commemoration. In Western Australia alone war memorials account for 55.6\% (194) of all memorials listed on the Heritage Council of Western Australia's database of places - 
although only 7 of these have full legislative protection. ${ }^{1}$ As sites of memory, mourning and ritual, war memorials have multiple and contested meanings and constitute a special class of place at the intersection of sorrow, citizenship and identity. With the above in mind this paper promotes the concept of cultural biography as an approach that may offer a more nuanced frame for examining war memorial significance than currently offered by conventional heritage assessment.

This paper offers the Katanning war memorial in Western Australia as a case study to suggest that a cultural biography approach can help capture a richer understanding of the community meaning of these places. In order to do this, the paper contextualises war memorials with a discussion on commemoration, examines the concept of cultural biography as a tool of analysis and then details how this might be applied in the context of war memorials. I argue that cultural biography may help to widen the understanding of the heritage significance of objects and places than currently possible with analysis derived from ICOMOS Burra Charter guidelines.

\section{Commemoration}

Most British Empire countries built war memorials after the conflagration of World War One. Forced by the enormity of losses and fostered by a 'will to remember', a substantial number of war memorials of all styles and descriptions were constructed (Nora 1989, p. 19). Memorials reoriented 'the memory of war away from violence and physical damage towards peace and community cohesion', and established reciprocity between the monument and the bereaved (Carden-Coyne 2009, p. 316). Not all the bereaved or returned soldiers thought that a memorial was an appropriate response. Some railed against the expense. It was money that could be better spent alleviating the 
suffering of soldiers or others affected by the war. In this vein Rowlands maintains that war memorials can work on two levels - on a personal level of healing and reconciliation and as an evocation of disgust and condemnation. There is also a 'temporal gap' between the function of the memorial as an initial place of healing where people 'live through' the mourning process and it becomes possible to forget the pain and the memorial as a place of closure. In effect the 'memorial', then, becomes a 'monument' (Rowlands 1999, p. 131).

Anzac, a complex concept that pervades Australian culture, primarily drives our war commemoration. Linked to Australian identity, its practice has all the trappings of a civil religion. Originating from Australia's engagement with Ottoman defenders on the slopes of Gallipoli in 1915, which was Australia's perceived rite of passage from colony to nation, it has been taken as our core national mythology and the Australian soldier or 'digger' as a template of personal and civic behaviour. While now distanced from the original generating events, it still underlines qualities to which Australians aspire and is embedded in our national identity, cultural outlook and the story of Anzac is presented as part of our national collective memory. The persistent retelling of the Anzac myth on Anzac Day reinforces the legitimacy of memorial sites as significant and 'sacred'. However, as with all national narratives, it has detractors and its tenets are often criticised. More recently Anzac (or at least its modern manifestations) has been accused of militarising Australian history (Lake et al. 2010) - a stance countered as naive or revisionist (Blainey 2010, Bendle 2009a, 2009b).

The concept of collective (or social) memory is a difficult subject and its meaning, opposed to individual memory, is contested when considering objects of public memory such as a war memorial. Maurice Halbwachs (1992) described collective memory as a complex social framework of shared individual memories that 
had the effect of helping a community to maintain its identity over time. Connerton $(1989$, p38) argues that practices of remembrance are a prime vehicle for the successful continuance of a shared memory. But, there is also an uneasy relationship between individual and collective memory through 'the atomization of general memory into a private one' (Nora, 1989, p. 16). Nevertheless, cognisant of the difficulty, I propose that for the purposes of this paper, collective memory as applied to a war memorial could be usefully described as 'the representation of the past, both that shared by a group and that which is collectively commemorated, that enacts and gives substance to the group's identity, its present conditions and its vision for the future' (Misztal 2003, p. 7.).

\section{Cultural biography}

Igor Kopytoff (1986) appears to have first developed the idea of cultural biography. He suggests that objects are invested with meaning through social interaction. However, what makes a biography 'cultural' is 'not what it deals with, but how and from what perspective' (Kopytoff 1986, p. 68). Here, the object is culturally constructed and that the 'eventful' biography of an object reveals its meaning as it shifts with age and context (Kopytoff 1986, p. 90).

Gosden and Marshall (1999, p. 169) further develop Kopytoff's biography concept. In their view the central idea is that, 'as people and objects gather time, movement and change, they are constantly transformed, and these transformations of person and object are tied up with each other'. The present significance of an object is the accumulation of a life history of associations with people and events to which it was connected. ' ...objects do not just provide a stage setting to human action they are integral to it'(Gosden and Marshall 1999, p 169). A 'life history' of objects and places 
is dynamic and inextricably linked to 'people and events' over the course of its existence. This provides a thick and rich process to capture the 'becoming' of a place or object and its meaning as an accumulation of a lifetime of social and physical interaction. In archaeology this differs from more functionalist approaches to 'life cycles' and 'use lives' of objects 'exploring their changing role and forms across time with particular emphasis on their appearance, manufacture and function' (O’Sullivan and Van De Noort, p. 70). In these cases the object is a '...passive, inert material to which things happen and things are done. Such analysis does not address the way social interactions involving people and objects create meaning' (Gosden and Marshall 1999, p. 169). Instead, '[m]eaning emerges from social action and the purpose of an artefact biography is to illuminate that process' (Gosden and Marshall 1999, p. 170). Here, my aim is to side step the problems that Gosden and Marshall outline in analysing objects and use the idea of cultural biography to examine the social life of a war memorial - to see how the cultural significance of a war memorial may be gauged by the relationships between the memorial and its public over time.

Recently, the 'cultural biography of landscape' has been used to develop a 'narrative of transformation' rather than a cycle of life in studies of the Netherlands landscape (Van Londen p. 171; Roymans et al, 2009, p. 339). Cultural biographical approaches have also been applied to war memorials. Young $(1989$, p. 70) analyses the shifting meaning of the Warsaw Ghetto Monument (built 1948) by tracking its biography over a forty-year period as a place of 'political and communal action'. Through a 'critical' biography of the monument's 'literal conception and construction amid historical and political realities' and reception or 'life in the mind of its community' he attempts to expose the development of Holocaust memorialisation 'between events and memorials, then between memorials and viewers, and then 
between viewers and their lives in the light of this memorialised past' (Young 1993, p. 71).

The current method of documentation and analysis of heritage places favoured in Australia derives from the ICOMOS Burra Charter guidelines for determining statements of significance. In Western Australia, for example, they are principally aesthetic and fabric driven (Heritage Council, 2002). ${ }^{2}$ Of course statements of significance do (generally) have regard for the social life of places. However, they tend to present places as passive rather than dynamic, not in the process of 'becoming'. I do not suggest that the present method of arriving at statements of significance should be overturned - although there is good argument that Burra Charter approaches have sizeable problems (Waterton et al 2006). However, a cultural biography approach may help give personal and community meaning a greater influence in heritage processes.

The implication of the above is that cultural biography is an approach that may help make connections between communities and war memorials to give particular social meaning and emphasise the uniqueness of a place shaped by changing contexts. The relationships that communities have had with their memorial over time indicate shifting values in concert with cultural contexts - how meaning and significance accrue and alter reveal the complex relationships and 'powerful innovative storylines about the way that communities have used, organised and interpreted objects and landscapes over time' (Roymans et. al. 2009, p. 355). This approach is useful in revealing the social life of the memorial and relationships that people have had with the memorial spaces, rather than just focussing on the memorial as an object. Memorials are not viewed as merely passive and inert places but rather places where the lives of people and objects are entwined. 


\section{Biography}

Katanning is a sprawling wheat belt town of nearly 4,000 people in Western Australia's Great Southern region. It is a prosperous place established in 1889 and located inland on the Great Southern Highway approximately 295 kilometres south east of Perth. It is an area where water is a relatively scarce commodity; Katanning relies on a variable rainfall of approximately 478 millimetres per annum. The town services the surrounding agricultural region of mostly wheat and sheep farming.

Figure 1. Map of the south west of Western Australia showing the location of Katanning (source author).

In addition to the main war memorial the town also possesses a Returned and Services League (RSL) rose garden with an obelisk, numerous honour boards from both world wars and a large memorial to the district women pioneers (1956). ${ }^{3}$ An immigrant's memorial (2001) and a Noongar Memorial (2005) celebrating the community contribution of local Indigenous people have also been erected. ${ }^{4}$ Katanning society also boasts a large Muslim population.

The war memorial is a life sized marble soldier statue on a granite plinth located on one corner of Prosser Park - a large and windswept semi-grassed area in the town. The use of a soldier statue is relatively unusual as only six were constructed in Western Australia after World War One out of over one hundred monumental memorials of all types. $^{5}$ 
War commemoration in Katanning began in 1916 with Anzac Day celebrated exactly one year after the Gallipoli landings. Reporting on this event the local newspaper emphasized that this was a great war for peace in the name of the Empire. Whipping up patriotic fervour the newspaper declared, 'when the history of the war comes to be written ... there will be pages in which Australians for all time will glory, and the descendants of Katanning families which gave their sons to the war will cherish added pride in the names they bear' (Great Southern Herald, 1916). Even at this remote corner of the globe, Katanning was a willing and eager participant in the British Empire and its wars and the report indicates that wartime participation sprang from local identity as much from national identity and regard for the empire.

Honour rolls and boards, which commemorated all those in the district that had answered the call, followed very quickly - as much an encouragement for enlistment as a source of pride or sorrow. Officiating at one of these ceremonies Alex Thomson, a popular local politician, called for a more substantial memorial to be built as soon as possible (Great Southern Herald, 1917). Thomson's son went to war in 1917 at age 19 and returned unscathed. Thomson's brother John (also from Katanning) went missing in action in Belgium in 1917 and is named on the Menin Gate at Ypres. Alex, obviously much affected by his brother's death, went to Europe in 1922 with the intention of finding his brother's grave and therefore had very personal reasons for establishing a war memorial (National Archives, B2455).

Thomson's speeches show he was clearly an empire man and advocated (as many others had in Western Australia) that all fit young men should enlist even though it was a 'terrible war'. He was tireless in promoting the honouring of those that had died in the war. His relationship to the memorial layered both public honouring and private grief a situation common amongst many others who had friends and relations named on 
the memorial. However, nowhere in his cajoling of the community does he mention his own loss.

Directly after the war had concluded in 1918, Thompson again proposed a permanent memorial (Great Southern Herald 1919). He suggested a memorial on a plinth of local and 'not imported' stone emphasising the localness of the material in his suggestions. ${ }^{6}$ Regardless of his enthusiasm his suggestion went unheeded although other forms of memorialisation such as trees, honour avenues and honour boards were embraced. In nearby Badgebup, the Warren family constructed a memorial soak (dam) to fallen soldiers and built a substantial church as a memorial to their fallen son Charles.

Eventually, in May 1920, Thompson's persistence bore fruit and a public meeting was called to discuss establishing a war memorial. Immediately the debate about the form of a memorial polarized. Thompson's suggestion that the memorial should be an obelisk was met with opposition bent on building a hospital wing although it was pointed out that a hospital was yet to be built. Proposals for a soldiers club and pavilion were also mooted. Finding the going tough the meeting appointed an executive committee to choose the form of the memorial although it was decided that the memorial should be specifically dedicated to the fallen (Great Southern Herald 1920a).

Further meetings and discussions over the next year were dogged by argument. While discussion drifted in favour of the raising of a monument, another argument began to coalesce around the siting of the memorial and setting. Some favoured a site in the town at the head of Albion Street. Others suggested a site opposite the Town Hall and a further group wanted the memorial placed near the railway station. Votes were taken and the railway station site emerged as the preferred setting. The design for the memorial was to be decided by competition (Great Southern Herald 1920b). 
Spearheaded by Thompson, partial funds were raised relatively quickly. Outlying districts were visited with a brass band to drum up support. The competition for the memorial matured and in a final vote, a life size soldier statue in white marble on a granite pedestal was chosen over a polished granite obelisk. By October of 1920 the formalizing of the list of 257 fallen had begun. The names were to be from the 'district' rather than the town of Katanning itself. The initial tardiness of the community in accepting the memorial proposal was probably due to this decision. Surrounding towns had begun to build their own memorials and some felt that there was no reason for duplication. In general, names were an important part of the process of commemoration after both World War One and World War Two (Lacquer 1994, p. 163). As with many memorials the Katanning war memorial honoured local dead and was specific to the grief and remembrance of local people. Names on the memorial were familiar to most who attended early ceremonies and some surnames appear more than twice as whole families were decimated by the loss of fathers, sons and brothers. Letters to the newspaper praise the memorial's 'quiet dignity' and testify to the personal loss 'of those of us whose loved ones lie at rest in different areas of combat' and the part played by the memorial to help assuage 'the great sorrow of their passing' (Great Southern Herald 1921b).

While memorial form and names were being settled the site decision had festered and a further meeting was called. Many could not travel the long distances from their homes to the original meetings had protested that their voice was not heard and demanded another vote. At a subsequent meeting the vote was put to five suggested sites and a new site emerged in the recreation ground - although it was criticised as a site exposed to muddy streets and a sports ground, incompatible with the solemnity of a memorial. 
Argument over the form and siting of a war memorial were played out across the empire (Shipley 1987, MacLean 1990, King 1998, Inglis 1995). While Inglis shows that arguments were common to memorial building in Australia the Katanning biography demonstrates a parochial quality to debates over conditions and commemoration. The Albion Street site was rejected as it was too busy and windy (obviating private ritual) and the original railway site rejected, because it was railway land subject to constant traverse by railway employees. Appropriateness of a site related to ease of private commemoration and 'wholesome' environs. The selection of a distinctive soldier statue further cements a unique local preference.

\footnotetext{
Figure 3. Katanning War Memorial showing reversed granite pedestal and marble statue (source author).
}

Western Australian luminary Brigadier-General Bessell-Brown unveiled the memorial on Anzac Day 1921 (Great Southern Herald 1921a). Speeches emphasised local fallen and the sorrow this had caused. The monument was placed diagonally to the corner of Cliffe and Carew streets and was set back approximately ten metres from the corner. Molly West remembers that as a small child of five or six (in about 1925) she stood on the road at an Anzac Day ceremony at the memorial. Subsequent services always spilled out onto the road in front of the memorial (personal communication 7 March 2010). A photograph of the opening ceremony bears out this habit and a description from 1922 reports over 1500 at the Anzac ceremonies (Sunday Times, 1922). At this point in the community's relationship with the memorial there are clear signs that, while part of a mass movement of memorial building, there is a local slant emphasised by the personal and communal relationships between the people and the memorial. Although there is reference to the wider meaning of Anzac and national 
sacrifice in the unveiling speeches, the memorial specifically perpetuates the memory of 'district' fallen and announces the 'district's' commemorative credentials within a developing national concept of Anzac (Great Southern Herald 1921a).

Anzac Day and Armistice Day ceremonies were held at the new memorial in the recreation ground unless weather forced ceremonies into the town hall. By 1935 attendance at ceremonies had diminished. Armistice Day attendance dwindled with 'diggers unable to attend because of business reasons' (The Listening Post 1935). By 1937, the local membership of the RSL had declined so much as to cause alarm (RSL $16^{\text {th }}$ Annual Congress 1932). ${ }^{7}$ In 1947, this had recovered to 260 members. Anzac Day in this year also saw a Dawn Service conducted as well as the traditional mid-morning service though attendance was described as 'poor' (The Listening Post 1948).

RSL plans in 1947 to build a memorial hall to honour World War Two dead faltered, and in 1951 a memorial plaque to the fallen was affixed to the existing war memorial amid a 'very poor attendance' (The Listening Post, 1951). By 1989 this plaque appears to have disappeared from the memorial (Great Southern Herald 1989). Another plaque was added in 1956 for local VC recipients. Services at the memorial continued over the course of the 1950s and 1960s. Lack of participants caused the traditional Anzac Day march to be scrapped in 1973 and only the Dawn Service was conducted (Great Southern Herald 1973).

At this time, Anzac and war commemoration had started to decline with the natural attrition of digger numbers. In Australia, there was an expectation that Anzac commemoration would shrink and disappear. In the early 1960s the appropriateness of Anzac Day as a national day was questioned and the drunken behaviour of exservicemen on the day was placed under scrutiny. Anzac was seen by some as a racist, intolerant and militaristic civil religion and an anachronistic pattern for citizenship that 
was out of step with new values being forged in the social revolutions of the 1960s and 1970s. Here, the community's relationship with their war memorial follows a similar pattern of decline to others in Western Australia and it was a trend that stimulated Ken Inglis to establish his major study of war memorials before (he and others believed) Anzac and memorials disappeared altogether (Inglis 1995, p. 9).

In 1987 the rifle on the statue was stolen and in the following year the marble statue was painted (by the RSL) khaki all over (including the face) and the bronze wreath on the plinth under was painted yellow. The memorial was now poorly presented and looked the worse for wear with its surrounds 'weedy and neglected'. (Inglis n.d.). The painting of the statue was probably a matter of the RSL trying to 'improve' the statue's appearance. Painting of soldier statues was common in the eastern states of Australia in the 1970s and 1980s (McKay and Allom 1984, p. 9). What is curious is that the Katanning statue was completely one colour and remaining so for thirteen years despite its continued use and later reorientation to face the Park. It is possible that the painting of the statue and the wreath was a local measure to counter declining Anzac interest.

Figure 4. Detail of statue (source author).

Eventually, in 1988, numbers attending the Anzac Day services increased. For the first time all local schools were represented and many wreaths were laid. The RSL claimed the resurgence was due to 'media coverage and a realisation of the occasions importance' (Great Southern Herald 1988). It signalled a general rehabilitation of Anzac in Australia driven in part by the memory boom and new political agendas and was evidenced in the plethora of anniversaries of wartime actions presented as nation forming events. Even so, despite increasing attendances, the memorial grounds were not 
in good condition and in later in 1989 the memorial was again the target of vandals and the rifle was stolen for a second time. Also in this year the recreation ground was converted into Prosser Park, formalised with trees and entry statements. In tune with this development the soldier statue and its plinth was turned 180 degrees to face the park. An avenue of palms was planted in front leading into the park. Community members were not pleased with the change and agitated to have the statue returned to its original orientation (Ainslie Evans personal communication 7 March 2010). The reorientation of the memorial appears to have been an attempt to provide a more comfortable space for ceremony and the planting of palms to provide a formal approach. A long-standing objection to mixing sport with war memorials (as shrines to the fallen) was allayed. With its back to the sports ground and securely separated with a fence the memorial had carved out its own cosy sacred space. This intimacy was lost when it was turned around to face the newly formed park. Despite the reorientation, maintenance was poor and the memorial still lacked dedication to World War Two (the original plaque was apparently lost), Korea or Vietnam.

In 1990, intentions to restore the now dilapidated and 'shoddy looking' memorial were not achieved (Great Southern Herald 1989b). Despite its dilapidation and disconcerting khaki colour the memorial continued to be the focus of Anzac Day ceremony and in 1990 - the $75^{\text {th }}$ anniversary of the landings at Gallipoli - record attendances were reported (Great Southern Herald 1990). The record of ceremony on this occasion marks a Dawn Service at the memorial and a mid-morning ceremony in the town hall followed by a march to the memorial by the RSL and other community groups. In 1995, a plaque commemorating World War Two was affixed to the memorial courtesy of funding from the 'Australia Remembers $1945-1995$ ' project. $^{8}$ 
In 2002 the statue was taken from its plinth, paint stripped and surfaces repaired - including missing hands, fingers and rifle. It was returned to face the corner (its original position) so that 'people will finally be able to see the soldiers face' (Great Southern Herald 2002). While the statue faces the street corner, the plinth remains facing the park.

Figure 5. Rear of memorial showing plinth facing park and statue facing road corner (source author).

Once again, Anzac Day services spilled out onto the road forcing closure to traffic. In 2007 , further attempts to remove the rifle by vandals destroyed the replacement rifle and the hand holding it. While there has been a renewed spirit of rehabilitation in the community's relationship with the memorial, vandalism indicates that there are iconoclastic attitudes at work in this memorial space. Vandalism is explained as 'youthful high spirits' (Ainslie Evans personal communication 7 March 2010). This is contradicted by other comments that the statue now exists in a less affluent part of town and that these people do not treat the memorial with respect (Alan Barnes personal communication 24 October 2007). Clearly not all regard the memorial as significant and this is perhaps a natural function of both the new immigrant population and the distance in time from the originating events of Anzac despite the resurgence of war commemoration. However, merely because people do not find a memorial significant it does not follow that they would be willing to vandalise it. However, it does raise interesting questions on how Anzac will be relevant for 'multicultural' Australia in the future - questions beyond the scope of this paper. Vandalism is a complex problem and in the case of the Katanning memorial, it indicates that the 
significance of the memorial as a sacred place, in the traditional Anzac sense, is not secure.

Recently the memorial area has been paved with brick although the original chain fence still addresses the corner and delineates the space. An arc of young palms has been planted around the rear of the memorial space in an attempt to define the space from the large area of park behind. The memorial shares this area with a small stone dedicated those who served and died in Vietnam and with an Ottoman trophy gun captured in World War One. Documentation on the unveiling of the Vietnam memorial is unavailable and there is no report of this in the local newspaper. The small Vietnam memorial stone denotes a prickly relationship that local Vietnam veterans have had with this memorial, its RSL custodians and Anzac Day in general. Australia wide the reception for returning Vietnam soldiers was patchy. Some were welcomed back with tickertape and others refused admission to RSL branches. As a gesture of reconciliation the Katanning RSL held a Vietnam Veterans day ceremony at the memorial in 2007 but it was not attended by any of the veterans (Alan Barnes personal communication 24 October 2007). Vietnam veterans have tended to develop their own memorials and commemorations. Aboriginal service is another exclusion from the memorial $-\mathrm{a}$ situation that has been addressed at many other memorials across the state. Anzac Day services continue to be held at the memorial attracting around 350 or more people, roughly $11 \%$ of the present Katanning population.

So far, this biography reveals three very broad stages in the life of the memorial and its relationship with the community: the initial stages of its production and interwar use; its declining fortunes and apparent neglect after World War Two; and more recent relationships since the mid-1980s. 
The memorial emerged due to the enthusiasm of Alex Thompson. While driven by his boundless public spirit and devotion to empire, he was also motivated by personal grief. He was not alone in the community in either wanting to honour the fallen or memorialise loved ones. The district dead was approximately $16 \%$ of the total men who marched off to war (Great Southern Herald 1921a). However, while the debates about location and memorial form were universal, these arguments were localised and coloured by a consideration of how to commemorate 'their' local heroes and how 'their' district would be identified in its contribution to World War One. Here too is a curious mix of sorrow, loss and pride in the achievements of the fallen - emphasised in Anzac Day speeches. Memory of the fallen was still fresh in the community's mind. The biography uncovers ambivalence to the building of the memorial - partly because other memorials around the district were already built or planned and it was seen as duplication. Direct opposition to the memorial on moral grounds is not uncovered as these sentiments were probably left unsaid and unrecorded in the close rural social environment after the war. The fall in community interest in commemoration in the years between World War One and World War Two is a complex issue and involves the declining influence of the RSL, the many problems encountered by ex-servicemen on their return, public jealousy and suspicion of servicemen and the fading of public war memory.

Good relations with the memorial after World War Two was partly due to returning soldiers and because war memory was still fresh. This tapered off towards the 1980s. The decline of the Katanning community interest in war commemoration and its rituals was in concert with the national decline of Anzac as a pattern for citizenship. Donaldson and Lake (2010) believe that the RSL, through its conservative and exclusive attitudes, was instrumental in the failing fortunes of Anzac Day (Donaldson 
and Lake 2010, p. 93). At no time in the life of the memorial did the RSL actually represent 'the community' and its membership and influence declined overall from World War One, although as an elite organisation it still held political clout and it tightly controlled Anzac ritual. At Katanning the decline in appreciation of Anzac was manifest in apparent attempts to make the statue more attractive by painting it. Public ennui towards war commemoration set in and the memorial and its surrounds faltered although Anzac rituals were still conducted. Though immersed in a national commemorative context there was a more complex local story to its neglect than simply a failing national mythology. Anzac day speeches rung with reference to World War Two and later Korea and Vietnam but there was no physical reference to these on the memorial space itself. To many the memorial probably appeared exclusively for World War One, a view reinforced by the image of the digger in archaic army dress. This limited its reference to those with experience of later conflicts. Its exclusiveness might have also contributed to the view that Anzac was no longer relevant and that the events it remembered were without currency and deep in the past. It was not until 1995 that the memorial began to acknowledge other conflicts.

There are two important themes threading their way through the biography localness and exclusiveness. While the memorial is a synecdoche - representing the whole complex story of Anzac - it is still a local product borne of local concerns rooted in place. The biography shows that whatever national or political contexts exist at a point in time there are local responses. Bauman argues that national agendas and cultural identity frames are prey to reinterpretation by communities who remould them to suit their own narratives and aspirations (Bauman 1995, p. 151). In this context local memorials have a tendency to loosen the national grip on Anzac, mould it to local concerns and establish complex sites of contest (between the national and the local) 
where there is a slow 'uneven erosion' of the national. There is also a tendency for ceremony to focus on locals who died as a dominant part of the nationally collective 'fallen'.

Also highlighted is exclusiveness in relations between the community and the memorial. Physically it has been one of excising the space of the memorial from its surroundings - ostensibly to heighten its distinctiveness as a sacred space.

Exclusiveness was much less defined when the memorial was turned to face the expanse of park landscape. Reversal of the memorial has again excised the memorial from the park - albeit tenuously. This indicates that sacredness is still a required condition of the memorial space, which must be separated from others. While an absence of funding may have had some effect on lack of recognition of recent wars (solved by the 1995 'Australia Remembers' project) the biography points to a measured exclusion of Vietnam veterans and Aboriginal services personnel - a situation that the present community is anxious to address.

Its locality in a rather soulless open suburban environment add to its isolation although the area is kept neat by the town council and there has never been any thought of moving the statue to a more conducive place. This points to a strong interweaving of memories of the place garnered over its 'becoming' with its symbolic Anzac and war memory role that overrides any consideration of improving its relatively uncomfortable position and its antiqueness in the face of more modern and abstract memorials built elsewhere in the state.

\section{Conclusion}


James Young contends that some memorials become 'invisible', contributing to neglect. He argues that while monuments are erected to attract attention they also have an essential stiffness that '... vitrifies its otherwise dynamic referent, a monument turns pliant memory to stone. It is as if a monument's life in the communal mind grows as hard and polished as its exterior form, its significance as fixed as its place in the landscape' (Young 1993, p 13). The biography of the Katanning war memorial is necessarily brief, but it reveals that the monument's meaning has not atrophied despite its uneasy and sometimes weak relationship with the townspeople.

The biography also reveals that Katanning has had (and still has) an ambivalent relationship with the memorial - and commemoration in general. The approach shows that, although it exists in a wider historical context of global and national influences, it is unique to this particular place and is the product of local concerns and processes that have moulded national frameworks to suit local conditions. The memorial has multiple meanings that emerge through a rich variety of relationships it has had with people over time emphasising that 'heritage is always the dynamic work of people, with processes of cultural transmission and the construction of values and identities being inextricably bound up with one another' (Van Londen 2006, p. 171). It shows that an approach focusing on the relationships that this memorial has with the people who have used and abused it might present a deeper cultural significance resulting from those relationships. The memorial is revealed as a dynamic space whose meanings are shaped by community interaction rather than as an object that 'has things done to it', uncovering complex meanings that reveal a deeper and more enduring understanding of its heritage significance.

\section{Notes}


${ }^{1}$ See the web site http://register.heritage.wa.gov.au/

${ }^{2}$ The Heritage Council of Western Australia conservation plan guidelines urges practitioners to address 'the sequence of development of the place based on the documentary and physical evidence' in their analysis of separate documentary and physical evidence.

${ }^{3}$ The Returned and Services League is a preeminent Australian ex-service organisation. No records survive to show why a second war memorial was necessary.

${ }^{4}$ Noongars are Indigenous people from the southwest of Western Australia.

${ }^{5}$ Soldier statues were more common in the other states of Australia and there is no record as to why Katanning took this decision.

${ }^{6}$ There is no indication that the memorial is of local stone although the sentiment indicates a preference to localise the memorial so that it had fidelity to place and referred to the environment of the fallen when alive.

${ }^{7}$ No figures exist for this year but membership in 1932 was 43 and had declined since this time.

${ }^{8}$ The Australia Remembers $1945-1995$ project in 1995 was a Keating government initiative to celebrate the fiftieth anniversary of the end of World War Two in Australia.

\section{References}

Annual Congress 1932 Returned and Services League 16 ${ }^{\text {th }}$ Annual Congress 1932, Provisional Agenda Report No 1, Sub Branch Strengths, Box 21, RSL State Branch Archives. 
Bauman, Z., 1995. Searching for a Centre that Holds. In: M. Featherstone, S. Lash and R. Robertson. Global Modernities. London: Sage Publications.

Bendle, M., 2009a. Gallipoli: second front in the history wars. Quadrant (June 2009), 614 ,

Bendle, M., 2009b. The assault on Anzac. Quadrant On Line. (7-8),

http://www.quadrant.org.au/magazine/issue/2009/7-8/the-assault-on-anzac.

Blainey, G., 2010. We weren't that dumb. The Australian, April 7,

www.theaustralian.com.au/news/arts/we-werent-that-dumb.

Borg, A., 1991. War Memorials. London: Leo Cooper.

Carden-Coyne, A., 2009. Reconstructing the Body: Classicism, Modernism and the

First World War. Oxford: Oxford University Press.

Connerton, P., 1989. How Societies Remember. Cambridge, Cambridge University Press.

Donaldson, C. and Lake, M., 2010. Whatever happened to the anti war movement? In:

M. Lake and H. Reynolds, eds. What's Wrong With Anzac? The Militarization of Australian History. Sydney: University of New South Wales.

Doss, E., 2010. Memorial Mania: Public Feeling in America. Chicago: The University of Chicago Press.

Gosden, C. and Marshall Y. 1999. The cultural biography of objects. World Archaeology, 31(2), 169-178.

Gough, P., 2004. Corporations and Commemoration: First World War Remembrance, Lloyds TSB and the National Memorial Arboretum. International Journal of Heritage Studies, 10, (5), 435-455.

Great Southern Herald, 1916. Anzac Day. Great Southern Herald, 29 April, p. 2. 
Great Southern Herald, 1917. The Roll of Honor. Great Southern Herald, 28 March, p. 2.

Great Southern Herald, 1919. A Permanent Memorial? Great Southern Herald, 6 August, p. 4.

Great Southern Herald, 1920a. Public Meeting, Great Southern Herald, 22 May, p. 3. Great Southern Herald, 1920b. Katanning War Memorial, Public Meeting in Town Hall, Great Southern Herald, 26 June, p. 2.

Great Southern Herald, 1921a. Anzac Day Celebrations, Great Southern Herald, 27 April, p. 2.

Great Southern Herald, 1921b. J.C Warren, letter to the editor, Great Southern Herald, 30 April, p. 2.

Great Southern Herald, 1973. Anzac Day March Cancelled, Great Southern Herald 19 April, p. 1.

Great Southern Herald, 1988. Anzac Day, Great Southern Herald, 27 April, p.3 Great Southern Herald, 1989a. Shire to Restore Honour Roll, Great Southern Herald, 7 June, p. 9.

Great Southern Herald, 1989b. RSL to Fight Roll Decision, Great Southern Herald, 5 April, p 2.

Great Southern Herald, 1990. Record Crowd Remember the Anzacs, Great Southern Herald, 2 May, pp. 1-2.

Great Southern Herald, 2002. About Face for Digger, Great Southern Herald, 5 June, p. 11.

HCWA, 2002. Conservation Study Brief: Introduction to Conservation Plans. Perth: HCWA (Heritage Council of Western Australia). 
Inglis, K. S., (n. d Papers of Ken Inglis, (War Memorials Project), PR00944 Canberra: Australian War Memorial.

Inglis, K. S., 1998. Sacred Places: War Memorials in the Australian Landscape.

Melbourne: Melbourne University Press.

Jalland, P., 2006. Changing Ways of Death in Twentieth Century Australia: War, Medicine and the Funeral Business, Sydney. UNSW Press.

Katanning Jubilee, 1939. Katanning Jubilee: A complete history of the town's progress from 1889 to 1939 issued to commemorate Katanning's 50 $0^{\text {th }}$ year. Katanning: Great Southern Herald.

King, A., 1998. Memorials of the Great War in Britain: The Symbolism and Politics of Remembrance. Oxford: Berg.

Kopytoff, I., 1986. The cultural biography of things, In: A. Appadurai, ed. The Social Life of Things: Commodities in Cultural Perspective. Cambridge: Cambridge University Press, 64-91.

Lake M. and Reynolds H., 2010. What's Wrong With Anzac? The Militarization of Australian History. Sydney: University of New South Wales.

Laqueur, T. W., 1994. 'Memory and Naming in the Great War'. In: J. R. Gillis ed. Commemorations: The Politics of National Identity. New Jersey: Princeton. See also Maclean, C. and Phillips, J., 1990. The Sorrow and the Pride: New Zealand War Memorials. Wellington: Historical Branch, Department of Internal Affairs.

McKay, J. and Allom, R., 1984. Lest We Forget: A Guide to the Conservation of War Memorials, Brisbane: Returned and Services League.

Misztal, B., 2003. Theories of Social Remembering, Maidenhead: Open University Press. 7. 
Moriarty, C. 1995. The Absent Dead and Figurative First World War Memorials.

Transactions of the Ancient Monuments Society, 39, 8-40.

National Archives, 1918. Service Records, 3222 Thomson, John Charles. B2455.

Nora, P., 1989. Between Memory and History: Les Lieux de Mémoire, Representations.

26, (Spring 1989), 7-24.

Osborne, B., 1998. Constructing landscapes of power: the George Etienne Cartier monument Montreal. Journal of Historical Geography, 24(4), 413-458.

O'Sullivan, A. and Van De Noort, R. 2005. Temporality, Cultural biography and seasonality: rethinking time in wetland archaeology, Archaeology from the Wetlands: Recent Perspectives, 11th Annual WARP Conference, September 2005, Edinburgh: The Society of Antiquaries of Scotland.

Reed, L., 2004. Bigger than Gallipoli: War History and Memory in Australia. Perth: UWA Press.

Rowlands, M., 1999. Remembering to Forget: Sublimation as Sacrifice in War Memorials. In: A. Forty, and S. Kuchler, eds. The Art of Forgetting. Oxford: Berg. Savage, K., 2009. Monument Wars: Washington DC, the National Mall and the Transformation of the Memorial Landscape. Berkley: University of California. Roymans, N., et al., 2009. Landscape Biography as Research Strategy: the Case of the South Netherlands Project. Landscape Research, 24(3), 337-359.

Scates, B., 2006. Return to Gallipoli: Walking the Battlefields of the Great War. New York: Cambridge University Press.

Scates, B., 2009. A Place to Remember: A History of the Shrine of Remembrance. Melbourne: Cambridge University Press. 
Scates, B., 2009. Manufacturing Memory at Gallipoli. War Memory and Popular Culture. In: M. Keren, and H. Herwig, eds. War Memory and Popular Culture. North Carolina: McFarlan.

Seal, G., 2004. Inventing Anzac: The Digger and National Mythology, St Lucia Queensland: Queensland University Press.

Shipley, R., 1987. To Mark our place: A history of Canadian War memorials, Toronto: NC Press Ltd.

Sunday Times, 1922. 'Katanning Anzac Service', Sunday Times, 30 April, p 1. The Listening Post, 1935. Sub Branch Activities: Katanning, The Listening Post, 16 December, p. 23.

The Listening Post, 1948. Sub Branch Activities: Katanning, The Listening Post March 1948, p. 19.

The Listening Post, 1951. Sub Branch Activities, Katanning, The Listening Post, April, p.23.

Todman, D., 2009. The Ninetieth Anniversary of the Battle of the Somme. In: M. Keren and H. Herwig, eds. War Memory and Popular Culture, North Carolina: McFarlan Yilmaz, A. B., 2007. Remembering War in Gallipoli: Under the Control of Architectural Memorialisation. The International Journal of the Humanities 5(1), 93102.

Van Londen, H., 2006. Cultural Biography and The Power of Image. In: W. Van Der Knaap and A. Van Der Valk, eds. Multiple Landscape, Merging Past and Present. Wageningen: Wageningen University.

Waterton, E., Smith, L. and Campbell, G., 2006. The utility of discourse analysis to heritage studies: The Burra Charter and social inclusion. International Journal of Heritage Studies, 12(4), 339-355. 
Winter, J., 1995. Sites of Memory, sites of Mourning: The Great War in European

Cultural History. Cambridge: University Press Cambridge.

Young, J. E., 1993, The Texture of Memory: Holocaust Memorials and Meaning. New Haven: Yale University Press.

Ziino, B., 2007. A Distant Grief: Australians, War Graves and the Great War. Perth: University of Western Australia Press. 